\title{
The Rural Market and Urban Market Integration: A Marketing Panacea to Economic Development Issues of Zimbabwe
}

\author{
Clever Vutete \\ MBA, Msc Marketing, BCom Marketing Management, Lecturer, ZOU-Harare Region \\ Tel: 263-772-458-026Ｅ-mail: vusabhuku@gmail.com
}

Farai Chigora (Corresponding author)

MBA, BCom Tourism and Hospitality Management, Lecturer

Catholic University of Zimbabwe-Harare, DBA candidate with University of KwaZulu Natal

Graduate School of Business Leadership, Westville Campus, South Africa

Tel: 263-772-886-871Ｅ-mail: fchigora@yahoo.com

Received: January 19, 2016 Accepted: February 4, 2016

doi:10.5296/ber.v6i1.9168 URL: http://dx.doi.org/10.5296/ber.v6i1.9168

\begin{abstract}
While many Zimbabweans are searching for foreign based economic opportunities for trade and exchange, the local market can also be used as a source of adding value through identifying and capitalising on the existing domestic absolute and comparative advantages. The development of linkages between rural markets and urban markets based on agricultural produce, farm implements, manufactured products and furniture products were used as case study products for identifying and evaluating comparative advantages in this study. A quantitative approach that collected and analysed rural and urban product units and price perceptions of 40 rural peasant farmers and 20 urban business people was used. The study established the comparative advantages that outweighed transport costs in the domestic rural and urban trade opportunities. Major products that attracted comparative advantages were cattle, goats, maize, ground nuts, farm implements, furniture and packaged food products. The research was unique due to its focus on stimulating inbuilt economic development projects.
\end{abstract}


Keywords: Local market, Comparative advantage, Absolute advantage, Rural-urban integration, Poverty.

\section{Background of the Study}

The African continent is generally labelled as having dangers of chronic poverty, conflict, economic collapse and institutional collapse (Gatune \& Najam , 2011) though the economic distinctions between rural problems and urban problems are not emphasised in some cases. India's economic development momentum was said to be growing due to its interest in linkages between rural and urban economic activities (Tiriwari, Shahbaz \& Islam, 2013). The ascendancy of India to a recognised force in the economic and political landscape is an outcome of a well designed policy on domestic market reforms, reducing unemployment rate, reducing inequality by gender and wages, and rural-urban partnerships. One of the definitions of economic development stress on the need to transform a traditional dual- system society into a productive framework in which everyone contributes and receive benefits (Kooros \& Badeaux, 2007). Sustainable economic development is achieved when both urban and rural people are growing in their capacities (Akkoyunlu, 2013). This means Zimbabwe might need to integrate the economic activities of rural and urban population to achieve economic development. Though rural geographical regions vary in their agricultural specialisations, and levels of productivity and opportunities for local business activities, there is need to make a generalised trade opportunity analysis between rural and urban economies (Battisti, Deakins \& Perry, 2013). Battsti et al (2013) in their New Zealand study analysed the strategic behaviour of rural SMEs in comparison to urban SMEs in time of difficult economic conditions as those currently faced in Zimbabwe. It was found out that geographical areas have an impact on how economic conditions have influence on those businesses. This might reflect that spatial differences of economic activities can be exploited to produce profitable comparative advantages between rural and urban economies in the same national economy (Giulietti, Ning \& Zimmermann, 2012). Akkoyunlu (2013) pointed out that rural activities are mainly agricultural and its output is basically unprocessed. The uniqueness of urban centres is concentration on non-agricultural activities, consumption of processed foods, heavy manufacturing, specialised employment structure and a well developed service sector. In this case it can be noted that the source of comparative advantages between rural and urban economies are linked to their structural, cultural, resource endowments and other economic dimensions. Duguma (2011) recommend a well built infrastructure of roads, buildings and other communication lines that facilitate rural-urban linkages and exchange.

While Zimbabwe is crying and mourning the impact of sanctions, economic sabotage and mismanagement in some circles; a solution can be developed around the integration of rural economic activities and urban economic activities. While putting together urban people and rural people in one project had caused some co-operatives and projects to die, an opportunity of collaboration exist at trade and exchange levels (OECD, 2013; Sthapoulou, Psaltopoulos \& Skuras, 2004). The rural population is generally in demand for non-agricultural goods and services that are mainly available in major towns at lower prices than prices offered by the rural based general dealers. In times of drought, we usually find the maize seed (for food) being available in towns and other 'good climate' farming regions. Those in Gwanda, 
Beitbridge, Chiredzi (Chikombedzi and Malipati), Binga, Chivi, Mwenezi, Rushinga and Nkayi would be willing and able to pay for getting that maize for food but fail to buy due to shortage. They usually sell their good breed of goats and cattle to get money expecting to buy about two (2) tonnes of maize seed (for food) per each family. They would hold on to that money and fail to purchase the needed maize due to shortages at the business centres and even from Grain Marketing Board (GMB). The same people who have heads of cattle which range from 20 to 100 are sometimes labelled as poor, hungry, hopeless and unorganised! One of the writers personally stayed in Malipati (a Chiredzi South township) during the 1992 drought, and also witnessed the trends of the 2002 to 2003 drought years in Binga. The major problem was not that the rural people did not have money to buy maize ( Shangani-Chifake /Tonga- Chipokwe), but that the urban people through the social welfare department and GMB did not have the required quantities of maize. Our parents had to sleep on verandas of shops in queues for maize and mealie- meal holding their cash. Remember that in 1992 and 2002 the Zim-Dollar was still a strong currency! Though urban people are said to enjoy both higher private earnings and better public services than residents of rural areas (World Development Report, 2009), the other urban citizens are suffering more than rural people. This shows the need for trade to take place between urban and rural population. In a study by Oni \& Adepoju (2014), on the well being of rural households, the results showed a low mean value of well being status. The well being of families were generally high for male headed families, increasing educational levels, age of the family head, household size, and public service occupation.

There is also a situation where the urban society mainly in high density and middle density are wallowing in poverty and malnutrition related to the failure to access good food in enough quantities (Global Monitoring Report, 2013; von Braun, 2007). The urban people usually eat (Genetically Modified Organisms) GMO chicken and other meat products. Urban society craves for 'Road Runner Chickens', goat meat, nutritious beef, rural based fruits and even vegetables. The little income earned by the urban society is spent on expensive meat products, vegetables and other products that can be bought at cheaper price from the 'rural economy'.

When the urban economic systems ignore the rural economic activities, poverty, diseases and conflicts usually grow (Afsar, 1999). In due course the respective governments will be forced to make the urbanites pay drought levy, HIV/AIDS levy, subsistence levy and other taxes. While some of these policies aim at achieving equity in the rural-urban income distribution through simple transfer of income from those labelled as rich, this study focused on establishing sustainable 'intra-economy' trade based on the theory of comparative advantage and economic integration. Though other researchers on urban- rural integration focus on youth empowerment, gender roles, health and welfare, and some related concepts (Gatune \& Najam, 2011; Afsar, 1999; Valentinov, 2012), this study concentrate on finding out the comparative advantages that exist between selected marketing cases of rural Zimbabwe and the urban Zimbabwe on common products that were easily accessed by urbanites and those in surplus to rural residents.

\section{Research Objectives}


1. To analyse the expected prices and monetary exchange ratios between the rural and urban markets on selected products.

2. To determine the barter trade prices of common products, the domestic opportunity cost ratios and illustrate the production possibilities of an average individual rural and urban household.

\section{Assumptions}

1. Rural customers usually have less cash than urban areas in Zimbabwe

2. Day to day expenses of rural people differ with those of urban areas.

3. Rural people are highly sensitive to high prices than urban areas.

4. Urban population is now searching for ways of cutting expenses in their purchase and consumption decisions.

5. Poverty is felt by both urban and rural residents.

\section{Literature Review}

\subsection{Theories of Inter-Economy Trade}

The first theory of trade in this reflection is the Mercantilism. It directs governments to establish policies that expand exports and reduce imports so as to create a trade surplus (Katsioloudes \& Hadjidakis, 2007). A trade surplus enabled governments to sell the additional 'foreign currency' in exchange for gold. Adam Smith (1723-1790) on the 'An Inquiry into the Nature and Causes of The Wealth of Nations', published in 1776 emphasised that economies will exchange goods only when the other had absolute advantage in one of those products (Katsioloudes \& Hadjidakis, 2007). In our case the rural people will specialise in production of certain goods different from those concentrated on by the urbanites. He believed that poverty will be eradicated when each economy specialise on the areas where it can do best and then import those products in short supply. Each economy needs to produce products where it has an absolute advantage (Chacholiades, 1981). In our case we believe that the total output (GDP) of Zimbabwe will be higher if rural people and urban people specialise on what they can do best. The problem of specialisation, however, is that it could be risky if the trading partner fails to deliver the expected quantities. David Ricardo's (1817) theory of comparative advantage showed that it was profitable for nations to specialise in producing goods where they have a lower domestic opportunity cost ratio (Lasserre, 2003). The Heckscher-Ohlin Theory's application to rural-urban market integration encourage each side to intensively use the labour, capital, raw materials, land and social skills that are locally abundant (Katsioloudes \& Hadjidakis, 2007). The advantage of this model is on protecting people from shortages of products which might not be produced if the other economy stops production.

\subsection{Theory of Comparative Advantage and The Rural-Urban Trade}

The theory of comparative advantage seems to be more plausible in explaining and influencing the need for trade between poor and rich nations (Lassere, 2003). The trade between rural and urban centres will go ahead as long as the costs of producing a product in one of each area are greater than the other. Since the Ricardian comparative theory was based 
on the differences in labour skills and effort, this might also assist to explain differences in economic activities of rural and urban areas/zones (Reimer, 2010; Tacoli, 2004).

The basic assumptions of the Ricardian Theory as applied to the rural-urban integration are listed below:

1. Assumed labour to be the only critical factor.

2. Productivity of labour differs between countries or areas.

3. Labour is mobile within an area or country.

4. Productivity and efficiency is at its maximum in each area.

5. There are no impediments of trade between rural and urban areas.

The simplified analysis and calculation of opportunity cost ratios are illustrated by the assumed values of wine and cloth for Portugal and England. The figures in the table represent the total labour hours for producing each unit of either Wine or Cloth. We can say that Portugal had some absolute advantage in wine, since it uses few hours to produce the same unit than that of England. It also uses fewer hours (50 hours) to produce cloth than that of England (60 hours).

Table I. The Raw Figures of Labour Hours Used For Each Unit of Product

\begin{tabular}{|l|l|l|l|}
\hline Economy & Product: Wine & Product: Cloth & Comment \\
\hline Portugal & 20 & 50 & Absolute Advantage \\
\hline England & 120 & 60 & Absolute Disadvantage \\
\hline
\end{tabular}

Table 2. Domestic Opportunity Cost Ratios For Each Economy Using Labour Hours.

\begin{tabular}{|l|l|l|l|}
\hline Economy & Product: Wine & Product: Cloth & Comment \\
\hline Portugal & $20 / 50=0.4: 1$ & $50 / 20=2.5: 1$ & Wine is produced at lower opportunity cost in Portugal \\
\hline England & $120 / 60=2.0: 1$ & $60 / 120=0.5: 1$ & Cloth is produced at lower opportunity cost in England \\
\hline
\end{tabular}

Note: Those Ratios in Red are Domestic Opportunity Cost Ratios.

Portugal had the lowest domestic opportunity cost ratio of 0.40 labour hours in Wine production. So it had the comparative advantage in that product. England had the lowest domestic opportunity cost ratio of 0.5 labour hours in the cloth production. So it had the comparative advantage in that product. Though Portugal had an absolute advantage in the production of 'Cloth'-fewer labour hours, it had a comparative disadvantage in that product as they relate to England.

The Masvingo people are no longer producing much of (Mhunga/Millet/Inyauthi) and the Mash Central people are not producing enough Maize. If the economy faces any drought, the nation will suffer because of non-commitment on specialisation. That makes the Heckscher-Ohlin Theory to make sense.

Given that the theory encouraged developed economies like USA, UK, Germany, Japan and Canada to specialise on high tech and manufactured goods, it also mean that urban areas in Zimbabwe could also specialise on these type of products and ensure that they trade with the rural areas. The rural economy is also encouraged to produce more raw products of 
agricultural nature. The strengths of the Ricardian Law is that no person, firm, industry or country will be deemed too poor to be left out of the trade network (Thweatt, 1976). In a study by Jayawickrama \& Thangavelu (2010) on determining the comparative advantages among(between) Singapore, China and India, the results showed that China and India have comparative advantage in a broad range of manufactured products as compared to Singapore.

The study indicated that trade structures and processes between China, India and Singapore should be complementary due to the existence comparative advantages. Though India had some comparative advantages in a large category of products, it should complement with other countries (Jayawickrama \& Thangavelu , 2010). This means that even if urban centres think that they have comparative advantages in many products than rural people, they should engage in trade to complement each other. Korsgaard, Muller \& Tanvig (2015) preferred the use of the term rural entrepreneurship to describe rural economic activities that leverage local resources to reconnect place to space. The rural entrepreneurship has a potential for an optimal use of resources that can facilitate establishing the comparative advantages with the urban entrepreneurship (Korsgaard et al, 2015).

Policy makers, local governments, non-governmental organisations(NGOs) and business support agencies need to organise all the rural households to find out something they can produce and sell to urban people at a profit(Korgaard, et al, 2015).

Economic institutions and small businesses in rural areas were viewed to be 'resource poor' than those in urban centres. In the case of 'absolute advantage', the urban people are not likely to trade with rural people as they might view themselves to be richer than residents of rural markets. The theory of comparative advantage will make those in rural areas be viewed positively in terms of their output that is generally cheaper and more rewarding to urban exchange partners. The people in Gwanda, Binga, Rushinga, Chiredzi South and other rural zones will be viewed as rich enough to engage in meaningful intra-economy trade with surrounding urban areas. Business networks in rural areas are likely to be more dispersed than those of urban areas.

Technology gap always exist between urban and rural markets. The 'opportunity' based-view also views rural communities/economies as having limited markets than urban counterparts. The opportunity view can then have to see urban economies as market opportunities for the rural economies. Sun \& Wu (2004) also encourage the urban and rural economies to understand differences in purchasing and consumption behaviour in their rural or urban centres.

Some key features of rural customers are that they are price sensitive, are not attached to some brands, they buy under the influence of word of mouth rather than the mass media ( Sun $\& \mathrm{Wu}, 2004)$.

While the lifestyle differences between rural and urban people mainly express the levels of economic development differences in consumer behaviour, they also have a much bearing on how comparative advantages and opportunity cost ratios will be established.

The theory of comparative advantage might not produce results in Zimbabwe due to climatic 
change that might make some rural areas fail to produce their traditionally recognised crops and animals. Prices of commodities might change and make rural people fail to achieve much. Rural economies that also diversify into selling manufactured products and high tech are better.

Fuller- Love, Midmore, Thomas \& Henley (2006), in their research on rural entrepreneurship, acknowledged that rural areas face economic problems that need to be solved through scenario analysis that lead to rural economic regeneration. Rural areas were also encouraged to take advantage of their localised resource endowments and strengths (Fuller-Love et al, 2006). Future rural-urban integration opportunities should take account of the relations between society and economy, land use and other community concerns (Fuller-Love et al, 2006).

\subsection{The Need for Rural- Urban Integration}

Fearne, Alvarez-Coque, Mercedes \& Garcia(2013) in their study to analyse the capacity of rural and urban spaces for establishing innovation opportunities, found out that the rural/urban divide did not appear relevant concerning innovation levels. This might mean that rural people can also create products to sell to urban people. This reflects that spatial differences of economic activities can be exploited to produce profitable comparative advantage between rural and urban economies in the same national economy. Though there could be problems relating to units and type of products available in urban economies to those in rural economies, the \$US dollar expectations and existing 'domestic' barter system ratios could be used to establish areas of comparative advantages. Tiriwari, Shahbaz \& Islam (2013) established that financial development, economic growth and consumer prices aggravate the rural - urban income inequalities in the long-run. Though these inequalities exist, the comparative advantage ratios can still be established to facilitate mutually beneficial exchanges between the rural and urban economies.

\section{Research Methodology}

The study used a positivist research philosophy that applied quantitative strategies for establishing the quantity and price perceptions of tradable goods that appeal to both urban and rural residents. The initial phase involved establishing the common products that were in demand by both rural and urban economies in Zimbabwe. A survey questionnaire for the rural and urban respondents was designed and administered. It mainly focussed on finding out the way rural and urban economic participants perceived the monetary value and opportunity costs of products they need and also those they are offering to the market. The quota sample comprised of 40 rural based peasant farmers from Masvingo, Mashonaland Central, Mashonaland East, Mashonaland West and Midlands regions. A quota-judgmental sampling method was used. The 8 peasant farmers in each province were selected basing on them being known for crop, cattle, goats, maize farming, rural chicken breeding and cash generation capacity. The 20 urban business people in Harare were running some small to medium enterprises that ranged from restaurants, hardwares, bookshops, grocery shops and butcheries. The data from the 40 rural peasant farmers and 20 SME owners in Harare was collected through the face to face surveys. The analysis of data involved calculating average price 
differences between urban and rural economies, the rural to rural exchange ratios, urban to urban exchange ratios and the rural to urban exchange ratios. This was mainly based on the Ricardian Law of Comparative advantage. Graphical illustrations were also used to explain the possible exchange of some selected products basing on 'average household' level that simulated production possibilities of each sub-economy or market.

\section{Results and Discussion}

The feasibility of rural -urban integration is based on the existence of variations in price expectations and domestic opportunity cost ratios of each sub-economy or market in Zimbabwe. The results given on Table 3, 4, 5, 6 are basically averages derived from the response of 40 rural based peasant farmers and 20 urban based small business enterprises in Zimbabwe. The initial consideration is on dollar price differences and then selected barter trade value differences. Though high volume of data was collected, only major exchange prospects were discussed.

\subsection{The Dollar Price Expectations of Rural Dominant Products and Urban Dominant Products}

Rural-Urban market integration is facilitated by ability to exchange and trade on products and services produced in each economic sub-sector. The results indicate that products could be divided into 'rural -dominant' and 'urban-dominant' as shown by Table 3 below.

Table 3. The Dollar Price Expectations of Rural Dominant Products and Urban Dominant Products.

\begin{tabular}{|c|c|c|c|c|}
\hline Product for Exchange & $\begin{array}{l}\text { Average Price } \\
\text { Rural: } \\
\text { Expected }\end{array}$ & $\begin{array}{l}\text { Average Price } \\
\text { Urban: Expected }\end{array}$ & $\begin{array}{l}\text { Price Ratios: } \\
\text { (Rural: Urban) }\end{array}$ & $\begin{array}{l}\text { Nominal Price } \\
\text { differences }\end{array}$ \\
\hline \multicolumn{5}{|l|}{ (a)Rural-Dominant: } \\
\hline 1. Cattle per head & $\$ 326-00$ & $\$ 615-00$ & $1: 1.89$ & $\$ 289-00$ \\
\hline 2. Goat per head & $\$ 27-60$ & $\$ 45-00$ & $1: 1.63$ & $\$ 17-40$ \\
\hline $\begin{array}{ll}\text { 3. } & \text { Maize(Food) per } \\
& 20 \mathrm{Kg} / \text { Bucket }\end{array}$ & $\$ 6-35$ & $\$ 3-70$ & $1: 0.58$ & $-\$ 2.65$ \\
\hline $\begin{array}{ll}\text { 4. Groundnuts per } \\
\text { 20Kg/Bucket }\end{array}$ & $\$ 16-70$ & $\$ 23-00$ & $1: 1.38$ & $\$ 6.30$ \\
\hline $\begin{array}{ll}\text { 5. Rural } \\
\text { Chicken/'Road-runner' }\end{array}$ & $\$ 5-00$ & $\$ 8-40$ & $1: 1.68$ & $\$ 3.40$ \\
\hline $\begin{array}{l}\text { Average Price Ratio(Rural: } \\
\text { Urban ) }\end{array}$ & - & - & $1: 1.43$ & - \\
\hline \multicolumn{5}{|l|}{ (b)Urban- Dominant: } \\
\hline $\begin{array}{c}\text { 6. Farm Implements } \\
\text { i. Plough } \\
\text { Cart }\end{array}$ & $\begin{array}{l}\$ 220-00 \\
\$ 712-00\end{array}$ & $\begin{array}{l}\$ 150-00 \\
\$ 484-00\end{array}$ & $\begin{array}{l}1: 0.68 \\
1: 0.68\end{array}$ & $\begin{array}{l}-\$ 70-00 \\
-\$ 228-00\end{array}$ \\
\hline $\begin{array}{l}\text { 7. Home Furniture i. Sofas } \\
\text { ii Tables/Chairs }\end{array}$ & $\begin{array}{l}\$ 318-00 \\
\$ 153-00\end{array}$ & $\begin{array}{l}\$ 193-00 \\
\$ 96-00\end{array}$ & $\begin{array}{l}1: 0.61 \\
1: 0.63\end{array}$ & $\begin{array}{l}-\$ 125-00 \\
-\$ 57-00\end{array}$ \\
\hline
\end{tabular}




\begin{tabular}{|l|l|l|l|l|}
\hline $\begin{array}{l}\text { iii Kitchen Unit } \\
\text { iv Wardrobe }\end{array}$ & $\begin{array}{l}\$ 350-00 \\
\$ 250-00\end{array}$ & $\begin{array}{l}\$ 220-00 \\
\$ 120-00\end{array}$ & $\begin{array}{l}1: 0.63 \\
1: 0.48\end{array}$ & $-\$ 130-00$ \\
\hline $\begin{array}{l}\text { 8. Packaged food products: } \\
\text { i. Cooking Oil(2 Litres) } \\
\text { ii Sugar(2 Kgs) }\end{array}$ & $\$ 4-00$ & $\$ 3-00$ & $1: 00$ \\
\hline $\begin{array}{l}\text { Average Price Ratio(Urban } \\
\text { Dominant) }\end{array}$ & - & $\$ 2.00$ & $1: 0.80$ & $-\$ 1-00$ \\
\hline
\end{tabular}

The possible sources of rural absolute and comparative advantages were cattle, goats, ground nuts and the rural chicken (See Table 3). The average expected price of cattle in urban areas is almost twice that of rural areas (1 Rural: 1.89 Urban). Buying cattle for beef from rural areas will give the urban areas a net savings of around $\$ 289$ per animal before transportation and logistics adjustments. Goats give a savings of $\$ 17.40$ per unit, groundnuts give a benefit of $\$ 6.30$ per unit and the road runner chicken provides a $\$ 3.40$ advantage per unit. The urban based residents will make some savings on their meagre and over stretched salaries by trading with the rural economic participants. Though maize deemed cheaper to produce in rural areas, the research showed that the rural economy had an absolute and comparative disadvantage in maize production due to drought and low tillage of maize. Most rural people now favour growing cash crops like cotton and tobacco. This had exposed many families to poverty since the cash crop prices usually fluctuate in response to world price regimes. The overall price ratios in terms of rural to urban were \$US 1: \$US 1.43. The urban people will have a price advantage of \$US 0.43 per each dollar spent if they become integrated with the rural economy.

On the urban-dominant section, rural people expressed willingness to pay high prices for the ploughs and cart as key farm implements. They showed willingness to pay \$US 1 dollar for each \$US 0.68 price charged in town. This translated to price differences of \$70-00 more on the plough and \$228-00 more for the cart. This willingness to pay is caused by the impact the farm implements have on the farmer's day to day work. This means urban residents can purchase cheaper implements and sell these at lower prices to peasant farmers in rural areas.

The home furniture price is also expected to be higher in rural areas than for urban areas. Sofas can be accepted in rural areas with a price advantage of $\$ 125-00$, tables and chairs with \$57-00, kitchen unit \$130-00 and wardrobe with at \$130-00. Some rural areas were expecting lower prices of these furniture prices than what the averages show. Though they were estimating these prices at higher levels, they expected to first sell their cattle, goats, ground nuts and other farm produce to get funds for buying these urban dominant products. Some trusted on using cash crop money to buy these furniture products. Poverty is alleviated and eliminated when both rural and urban people use their limited budgets to buy more products. The prices charged to rural customers on packaged goods like cooking oil and sugar is generally higher than that paid by urban residents.

The overall price ratio for the urban-dominant products was found to be \$US 1 Rural: \$US 0.66 Urban. This indicates that urbanites are only charged $66 \%$ of the full price charged to rural customers. Given the comparative advantage of urban areas in these manufactured 
products and a comparative advantage of rural areas on the farm produce and animals, there is need for a co-ordinated trade link between the two markets.

\subsection{The Illustration of Domestic Opportunity Cost Ratios between Urban and Rural} Economies in Zimbabwe.

Table 4. The Rural Dominant Products Barter Exchange Ratios.

\begin{tabular}{|l|l|l|}
\hline Products & Average Exchange Ratios(Rural) & Average Exchange Ratios(Urban) \\
\hline 1.Cattle and Goats & 1 Cattle : 12 Goats & 1 Cattle : 7 Goats \\
\hline 2.Maize and Cattle & 1 Tonne Maize: 1, 5 Cattle & 1 Tonne Maize: 1 Cattle \\
\hline 3.Goat and Maize & 1 Goat : 3 Buckets of Maize & 1 Goat : 6 Buckets Maize \\
\hline 4.Ground Nuts and Rural Chicken & 1 Bucket Ground Nuts: 5 Chickens & 1 Bucket Ground Nuts: 3 Chickens \\
\hline
\end{tabular}

Table 5. The Urban Dominant Products Barter Exchange Ratios

\begin{tabular}{|l|l|l|}
\hline Products & Exchange Ratios(Rural) & Exchange Ratios(Urban) \\
\hline 1.Plough and Table Set & 1 Plough : I Table With Chairs & 1 Plough : 0.5 Table with chairs \\
\hline 2.Cart and Sofas & 1 Cart : 2 Sofas & 1 Cart : 3 Sofas \\
\hline 3.Kitchen Unit and Ploughs & I Kitchen Unit : 2 ploughs & 1 Kitchen Unit: 1 plough \\
\hline
\end{tabular}

Table 6. Rural- Urban Opportunity Costs For Selected Products

\begin{tabular}{|l|l|l|l|l|l|}
\hline Economy & Product: & Product: & $1^{\text {st }}$ Opp Cost: & $2^{\text {nd }}$ Opp Cost: & $\begin{array}{l}\text { Comment: Area With Comp } \\
\text { Advantage }\end{array}$ \\
\hline Rural & 10 Cattle & 120 Goats & $1 \mathrm{C}: 12 \mathrm{G}$ & $1 \mathrm{G}: 0.083 \mathrm{C}$ & Rural- Goats \\
\hline Urban & 10 Cattle & 70 Goats & $1 \mathrm{C}: 7 \mathrm{G}$ & $1 \mathrm{G}: 0.143 \mathrm{C}$ & Urban-Cattle \\
\hline Rural & 10 Maize $(\mathrm{t})$ & 15 Cattle & $1 \mathrm{M}: 1.5 \mathrm{C}$ & $1 \mathrm{C}: 0.67 \mathrm{M}$ & Rural- Cattle \\
\hline Urban & 10 Maize $(\mathrm{t})$ & 10 Cattle & $1 \mathrm{M}: 1.0 \mathrm{C}$ & $1 \mathrm{C}: 1 \mathrm{M}$ & Urban-Maize \\
\hline Rural & 10 Carts & 20 Sofas & $1 \mathrm{Ca}: 2$ So & 1 So $: 0.50 \mathrm{Ca}$ & Rural-Carts \\
\hline Urban & 10 Carts & 30 Sofas & $1 \mathrm{Ca}: 3$ So & 1 So $: 0.33 \mathrm{Ca}$ & Urban-Sofas \\
\hline
\end{tabular}

The table above was constructed by multiplying the average barter opportunity cost ratios by a multiple of 10. This was done to allow clear diagrammatic representation of the domestic opportunity cost ratios. See the Fig I, Fig II and Fig III below. 


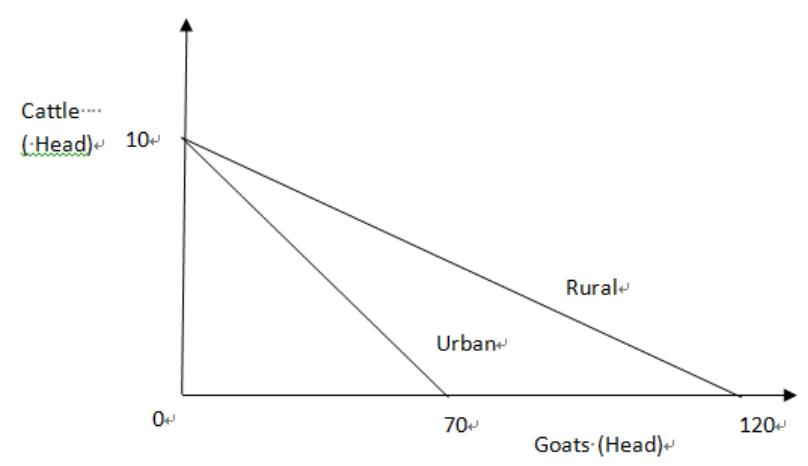

Fig I. Rural-Urban Comparative Advantages on Cattle and Goats

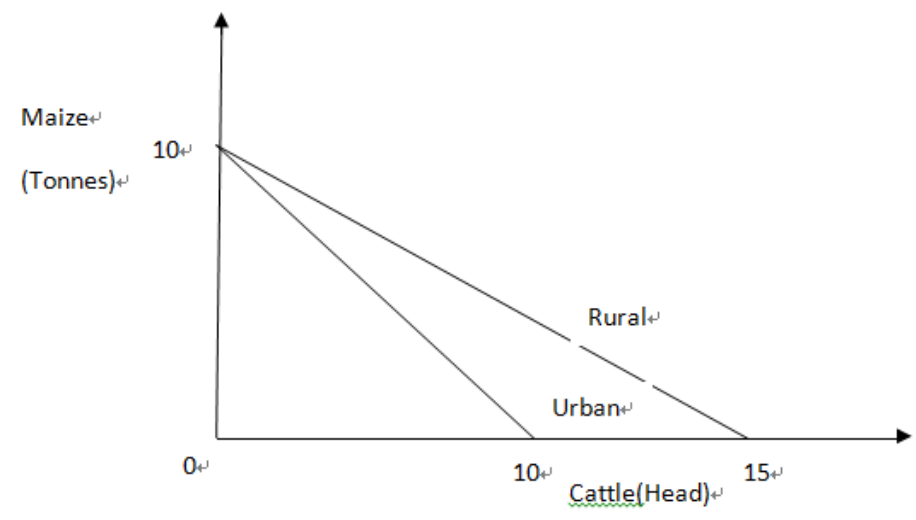

Fig II. Rural-Urban Comparative Advantages on Maize and Cattle

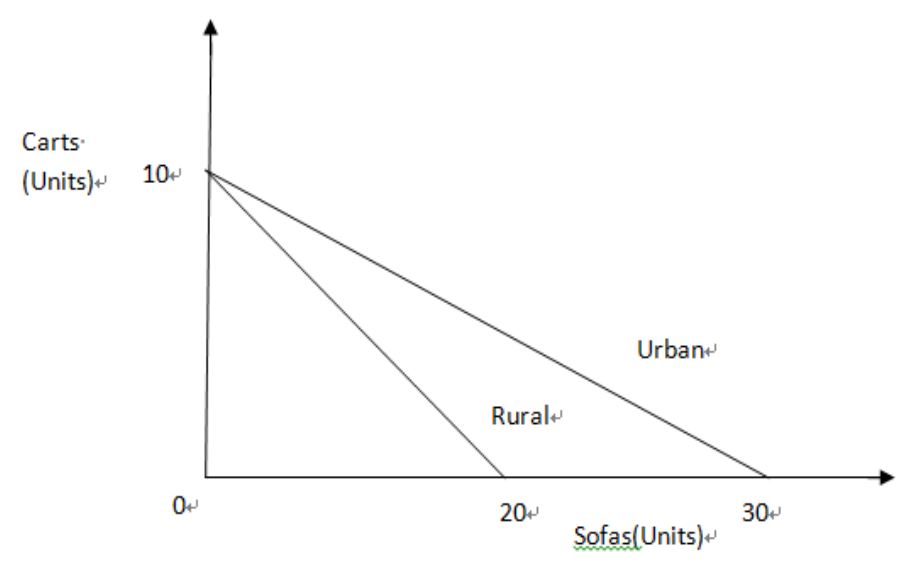

Fig III. Rural-Urban Comparative Advantages on Carts and Sofas

Rural areas have a comparative advantage in the production of goats (Fig I). The cost of producing 1 goat in rural areas is equal to 0.083 cattle, compared to 0.143 cattle in urban areas. It means the urban people can find ways of rearing or buying cattle elsewhere and exchange with goats from rural areas. This difference in perception could be caused by devaluation of goats by the urban based business people. Rural areas were found to have a higher comparative advantage in the production of cattle than in the production of maize (Fig II). The expected barter trade system by rural people is 1 cattle for 0.67 tonnes of maize, compared to 1 cattle: 1 tonne of maize in urban areas. Rural areas can produce carts at 
cheaper prize than what urban people can do (Fig III). The domestic opportunity cost ratio of Sofas is lower in urban areas than in rural areas. This could be caused by differences in skills. Some townships in rural areas were found to be able to produce and repair some carts to complement those from main urban centres.

\section{Conclusions}

The study results generally indicated that trade between rural people and urban people can be concluded basing on both absolute and comparative advantages. The integration of both rural and urban markets will lead to reduced cost of living and availability of products in demand. Barter trade expectations and dollar (\$) prices expectations were found to be slightly different in both urban and rural markets. The rural economy showed problems in getting seeds and chemicals, and also shortage of maize for food, especially in drought years. Urban residents showed a comparative advantage in supplying ploughs, packaged goods and furniture to rural areas.

\section{Recommendations}

The study recommends rural peasant farmers to concentrate on producing products that fetches large markets in town. Poverty is also reduced if urban people ensure that enough maize for food is supplied to the rural economy. The government is encouraged to form networks and market channels that facilitate rural-urban trade in Zimbabwe. The government should also stock more maize for food and sell it at effective prices to rural people when there is drought and to cover some intermittent shortages. The GMB can also buy cattle or goats in exchange of maize from the rural areas. The integration based on comparative advantages means that all economic participants, rural or urban, are critical for eradicating poverty in the economy. We recommend rural people to be provided with affordable seeds like cotton seed, vegetable seeds, maize seeds and tobacco seeds, and chemicals for both crops and animals.

\section{References}

Afsar, R. (1999). Rural-urban Dichotomy and Convergence: Emerging Realities in Bangladesh. Environment and Urbanization, 11, 235-46. http://dx.doi.org/10.1177/095624789901100106

Akkoyunlu S. (2013). The Potential of Rural-Urban Linkages for Sustainable Development,NCCR Trade Regulation Swiss National Centre of Competence in Research, Working Paper No. 2013/37.

Battisti. M, Deakins. D., \& Perry, M. (2013). The sustainability of small businesses in recessionary times, International Journal of Entrepreneurial Behavior \& Research, 19(1), 72-96. http://dx.doi.org/10.1108/13552551311299260

Chacholiades. M. (1981). Principles of International Economics, McGraw-hill, New York.

Duguma, E. (2011). Urban-Rural Linkages in Seru Town and its Hinterlands: Arsi Zone, Oromia Region. Thesis. Addis Ababa University.

Fearne. A, Álvarez-Coque,J. M. C, Mercedes,T. L. U., \& García, S. (2013). Innovative firms 
and the urban/rural divide: the case of agro-food system, Management Decision, 51(6), 1293-1310. http://dx.doi.org/10.1108/MD-12-2011-0482

Fuller-Love, N, Midmore P, Thomas D, \& Henley, A. (2006). Entrepreneurship and rural economic development: a scenario analysis approach, International Journal of Entrepreneurial Behavior and Research, 12(5), 289-305. http://dx.doi.org/10.1108/13552550610687655

Gatune J., \& Najam, A. (2011). Africa 2060: what could be driving the good news from Africa?, Foresight, 13(3), 100-110. http://dx.doi.org/10.1108/14636681111138794

Giulietti C, Ning. G, \& Zimmermann, K. F. (2012). Self-employment of rural-to-urban migrants in China, International Journal of Manpower, 33(1), 96-117. http://dx.doi.org/10.1108/01437721211212547

Global Monitoring Report, (2013). Rural-Urban Dynamics and the Millennium Development Goals. Washington DC: World Bank and International Monetary Fund.

Jayawickrama A. \& Thangavelu, S. M. (2010). Trade linkages between China, India and Singapore, Journal of Economic Studies, 37(3), 248-266. http://dx.doi.org/10.1108/01443581011061267

Katsioloudes M. I., \& Hadjidakis S. (2007). International Business: A Global Perspective, Amsterdam: Butterworh-Heinemann.

Kooros K. S., \& Badeaux L. M. (2007). Economic Development Planning Models: A Comparative Assessment, International Journal of Financial Economics, ISSN 1450-2887, Issue 7.

Korsgaard.S, Müller S., \& Tanvig, H. W. (2015). Rural entrepreneurship or entrepreneurship in the rural-between place and space, International Journal of Entrepreneurial Behavior \& Research, 21(1), 5-26. http://dx.doi.org/10.1108/IJEBR-11-2013-0205

Lasserre, P. (2003). Global Strategic Management, Palgrave-MacMillan, New York.

OECD. (2013). Rural-Urban Partnerships: An Integrated Approach to Economic Development. OECD Rural Policy Reviews. Paris: OECD Publishing. http://dx.doi.org/10.1787/9789264204812-en

Oni O. A., \& Adepoju. T, A, (2014). Analysis of rural households' wellbeing in Nigeria: a capability approach, International Journal of Social Economics, 41(9), 760-779. http://dx.doi.org/10.1108/IJSE-02-2013-0034

Overview. Prepared for OECD DAC POVNET Agriculture and Pro-Poor Growth

Reimer, B. (2010). Rural-Urban Interdependency as an Opportunity for Rural Revitalization. In The Rural-Urban Fringe in Canada: Conflict and Controversy edited by

Kenneth B. Beesley. Brandon, MB, Canada: Rural Development Institute.

Sridar G., \& Mishra D. (2011). Executives Social Representation of Rurality and Product 
Adaptation: A case of Rural Markets in India. Asia Pacific Journal of Marketing and Logistics, 23(3), 285-303. http://dx.doi.org/10.1108/13555851111143222

Stathopoulou. S, Psaltopoulos D., \& Skuras D, (2004). Rural entrepreneurship in Europe, International Journal of Entrepreneurial Behavior \& Research, 10(6), 404-425. http://dx.doi.org/10.1108/13552550410564725

Sun T., \& Wu, G. (2004). Consumption patterns of Chinese urban and rural consumers, $\begin{array}{llll}\text { Journal of } \quad \text { Consumer } & \text { 21(4), } & \end{array}$ http://dx.doi.org/10.1108/07363760410542156

Tacoli, C. (2004). Rural-urban Linkages and Pro-Poor Agricultural Growth Task Team Helsinki Workshop, 17-18, June.

Thweatt, W. O. (1976). James Mill and the Early Development of Comparative Advantage. History of Political Economy, 8(Summer 1976), 207-34. http://dx.doi.org/10.1215/00182702-8-2-207

Tiwari. A. K, Shahbaz, M., \& Islam, F. (2013). Does financial development increase rural urban income inequality?, International Journal of Social Economics, 40(2), 151-168. http://dx.doi.org/10.1108/03068291311283616

Valentinov, V. (2012). Understanding the rural third sector: insights from Veblen and Bogdanov, Kybernetes, 41(1/2), 177-188. http://dx.doi.org/10.1108/03684921211213016

Von Braun, J. (2007). Rural-urban Linkages for Growth, Employment and Poverty Reduction. Washington, DC: International Food Policy Research Institute.

\section{Copyright Disclaimer}

Copyright for this article is retained by the author(s), with first publication rights granted to the journal.

This is an open-access article distributed under the terms and conditions of the Creative Commons Attribution license (http://creativecommons.org/licenses/by/3.0/). 